\title{
Kesehatan Mental dan Perubahan Aktivitas-Perjalanan Saat Pandemi COVID-19 di Indonesia
}

\author{
Muhamad Rizki', Dwi Prasetyanto², Andrean Maulana ${ }^{3}$ \\ Institut Teknologi Nasional, Bandung, Indonesia \\ Email: muhamadrizki1404@itenas.ac.id ${ }^{1}$,dwipras@itenas.ac.id², \\ andreanmaulana@itenas.ac.id ${ }^{3}$
}

Received 30 November 201x | Revised 30 Desember 201x | Accepted 30 Januari $201 x$

\begin{abstract}
ABSTRAK
Pandemi COVID-19 telah secara signifikan mempengaruhi bagaimana kita menjalani kehidupan seharihari kita. Studi ini bertujuan untuk menginvestigasi dampak perubahan kesehatan mental kepada perubahan aktivitas dan perjalanan saat pandemi di Indonesia. Convenient sampling digunakan untuk menentukan jumlah sampel dan pengumpulan data dilakukan secara online pada masa pandemi dengan kuesioner. Adapun metode regresi linear berganda digunakan untuk menganalisis data. Hasil analisis menujukkan bahwa telah terjadinya perubahan aktivitas dan perjalanan akibat dari pandemi COVID-19. Tipe kesehatan mental seperti depresi dan bosan sangat berkaitan dengan penurunan pola perjalanan, sedangkan kelelahan berkaitan dengan berkurangnya kegiatan berbasis online. Studi ini juga menemukan bahwa masyarakat berpendapatan tinggi cenderung memiliki akses lebih baik terhadap platform online dan melakukan kegiatan online lebih banyak. Kelompok tersebut juga cenderung mengurangi perjalanan keluar tempat tinggal. Studi ini merekomendasikan pembenahan kualitas internet dan pembangunan fasilitas aktif (taman) dekat tempat tinggal untuk mengendalikan pandemi bersamaan dengan menjaga penurunan kesehatan mental.
\end{abstract}

Kata kunci: COVID-19, Aktivitas, Perjalanan, Regresi linear berganda

\begin{abstract}
The COVID-19 pandemic has significantly affected how we do our daily lives. This study aims to investigate the effect of emotional well-being to the changes in activity and travel during COVID-19 pandemic in Indonesia. Convenient sampling is used for dermine sampling size and online data collection was carried out during a pandemic using a questionnaire. Moreover, the multiple linear regression model is used for data analysis. It is found that there has been a change in activity and travel as a result of the COVID-19 pandemic. The results of the analysis show that several issues related to mental health, such as depression and boredom, are strongly associated with the decrease of out-of-home activities, while fatigue is associated with a lower ICT activities. This study also found that high-income people, which have higher accessibility to ICT, tend to do more online activities and also reduce their out-of-home activities during pandemic. This study propose improving the quality of the internet and building active facilities (parks) near residential location to manage the pandemic while maintaining a decline in mental health.
\end{abstract}

Keywords: COVID-19, Activity, Travel, Multiple linear regression 


\section{PENDAHULUAN}

Sejak pengumuman kasus pertama di Wuhan, Tiongkok, kasus pandemi Coronavirus Disease 2019 (COVID-19) di Indonesia pada Januari 2021 telah mencapai lebih dari 1 juta kasus ${ }^{1}$. Dikarenakan penyebaran kasus COVID-19 dapat terjadi akibat dari manusia ke manusia dan belum adanya pengobatan efektif untuk penyakit tersebut, berbagai negara di dunia melakukan penerapan pembatasan pergerakan [1]. Hal ini dilakukan untuk menjaga resiko penyebaran penyakit tidak melewati kapasitas infrastruktur kesehatan yang ada [2]. Penerapanan kebijakan ini sangat mempengaruhi bagaimana mobilitas masyarakat untuk memenuhi kebutuhan hidupnya sehari-hari.

Pembatasan ini telah berdampak secara signifikan kepada penggunaan angkutan umum dan lalulintas kendaraan bermotor di berbagai kota di dunia. Berdasarkan data dari Moovit [3] tentang dampak COVID-19 pada penggunaan angkutan umum, penggunaan angkutan umum di kota-kota di dunia seperti London, New York City, Berlin, Paris dan Sydney mengalami penurunan yang signifikan di tempat umum penggunaan transportasi. Di Paris, misalnya, penurunannya mencapai sekitar $80 \%$ dibandingkan tingkat sebelum pandemi. Senada, UITP [4] juga melaporkan bahwa pandemi tersebut telah menyebabkan 19\% operator bus India kehilangan 90\% penumpangnya dan sisanya $91 \%$ tanpa penumpang sama sekali. Indonesia juga mengalami kondisi ini, seiring dengan penurunan kapasitas (headway) dan pembatasan (load factor), sebagian besar penumpang angkutan massal (yaitu MRT, BRT, dan Commuter Rail) di Jabodetabek mengalami penurunan lebih dari 80\% dari kondisi biasanya [5].

Pandemi ini juga mengubah perilaku belanja masyarakat, karena masyarakat memaksimumkan aktivitas di rumah. Adaptasi teknologi informasi dan komunikasi (TIK) meningkat secara signifikan, termasuk belanja online. Menurut Clement [6], jumlah trafik website e-commerce dunia melonjak dari semula sekitar 12,81 miliar pada Januari 2020 menjadi 14,34 miliar pada Maret 2020. Sebuah survei yang dilakukan Kunst [7] di tiga negara maju yaitu Jerman, Inggris, dan Amerika Serikat mengungkapkan bahwa ada sekitar $4 \%$ hingga $27 \%$ responden yang mulai membeli berbagai produk secara online karena pandemi COVID-19. Tren ini juga serupa dengan yang terjadi di Indonesia. Merujuk pada Pusparisa [8], sektor e-commerce Indonesia mengalami peningkatan yang cukup tinggi saat terjadi pandemi, yang ditunjukkan dengan peningkatan penjualan bulanan sebesar $26 \%$ dibandingkan dengan tahun sebelumnya. Selain itu, jumlah transaksi harian juga meningkat dari 3,1 juta pada triwulan II 2019 menjadi 4,8 juta pada April 2020.

Pembatasan aktivitas di luar rumah juga ditemukan mempengaruhi kesejahteraan subjektif individu dan akibatnya kesehatan mental, karena beberapa aktivitas terlibat untuk menjaga atau meningkatkan kesejahteraan [9]. Studi dari Brooks et al. [10] pada karantina di pandemi sebelumnya menunjukkan berbagai masalah kesehatan muncul pada saat karantina. Dilaporkan bahwa masalah kesehatan mental meningkat seiring dengan jumlah hari selama lockdown, terutama bagi orang dengan kondisi khusus seperti OCD, depresi, dan ketergantungan zat [11]. Faktanya, bahkan bagi orang-orang yang tidak memiliki ketergantungan zat, rutinitas baru dengan tempat berulang yang terus menerus selama periode waktu yang cukup lama juga akan mempengaruhi kesehatan mental pribadi [12]. Belajar dari pandemi dan karantina sebelumnya, Brooks et al. [10], yang meninjau 24 makalah dari pandemi SARS dan berbagai karantina di seluruh kota, telah menemukan bahwa selama karantina masyarakat sangat mungkin mengembangkan berbagai gejala stres dan gangguan psikologis. Studi tersebut juga mencatat bahwa gejala stres pasca trauma terjadi.

Dampak pandemi kepada kehidupan sehari-hari sangat signifikan, namun mayoritas penelitian yang ada saat ini umumnya berfokus pada karakteristik penyakit COVID-19 [13] serta kebutuhan vaksin. Studi

\footnotetext{
${ }^{1}$ Perkembangan kasus COVID-19 di Indonesia dapat dilihat pada covid19.go.id Rekayasa Hijau - 126
} 
tentang analisis perubahan aktivitas dan perjalanan dan hubungannya dengan kesehatan mental belum banyak dilakukan di negara berkembang seperti Indonesia. Studi untuk memahami perubahan aktivitas dan perjalanan sangat penting untuk melakukan manajemen perjalanan saat pandemi ini dan antisipasi pada pandemi mendatang. Selain itu, studi yang mengintegrasikan aspek kesehatan mental sangat bermanfaat untuk merumuskan kebijakan untuk mencegah adanya penurunan kesehatan mental yang signifikan diakibatkan dari karantina untuk pandemi.

Selain itu, penyelidikan perubahan aktivitas perjalanan pasca COVID-19 di negara berkembang menjadi penting karena adanya perbedaan masyarakat, ekonomi, infrastruktur, dan budaya dan akibatnya berpengaruh terhadap dampak COVID-19, antara negara maju dan negara berkembang. Dalam kasus Indonesia, urbanisasi, bentuk perkotaan yang tidak efisien, dan kualitas internet yang rendah telah menjadi ciri daerah perkotaannya [14]. Dari segi pandemi, Indonesia melaporkan kasus pertama pada awal Maret 2020. Meski tidak seketat yang diterapkan di Wuhan, pemerintah Indonesia juga telah menerapkan berbagai kebijakan pembatasan aktivitas di luar rumah mulai minggu kedua Maret [15] dan setelah mengevaluasi pertumbuhan kasus di setiap provinsi, pada Juni 2020 beberapa kebijakan akan dilonggarkan. Oleh karena itu, studi ini akan memberikan wawasan baru untuk memahami perubahan perilaku aktivitas perjalanan dan implikasi pandemi di Indonesia sebagai representasi negara berkembang.

Berdasarkan latar belakang tersebut, secara spesifik tujuan dari dari penelitian ini antara lain: i.) mengetahui perubahan aktivitas dan perjalanan saat pandemi; dan ii.) menginvestigasi hubungan dari kesehatan mental dan aspek sosio demografi kepada tingkat perubahan aktivitas dan perjalanan. Dengan menyebarkan kuesioner secara online, data dikumpulkan dan dianalisis menggunakan metode analisis faktor dan regresi linear berganda. Makalah ini akan terbagi menjadi lima bagian. Setelah pendahuluan, pada bagian kedua akan disajikan metodologi perumusan kuesioner dan pengumpulan data. Selanjutnya analisis data dan pembahasan disampaikan pada bagian ketiga yang dilanjutkan dengan diskusi. Makalah ini akan diakhiri dengan penarikan kesimpulan.

\section{METODOLOGI}

\subsection{Pengumpulan Data}

Pengumpulan data dilakukan untuk menangkap perubahan aktivitas dan perilaku perjalanan selama pandemi yang melihat sebelum pandemi sebagai acuan. Untuk menyelidiki faktor-faktor yang mempengaruhi perubahan aktivitas perjalanan saat pandemi, studi ini menggabungkan pengaruh karakteristik sosio-demografis dan perjalanan individu, penggunaan dan pengalaman TIK, sikap terhadap COVID-19, dan perilaku untuk mencegah infeksi penyakit juga sebagai kesejahteraan subjektif. Setelah serangkaian tinjauan pustaka terkait perilaku perjalanan [16] dan determinannya seperti sikap [17], kesehatan mental/well-being [18], dan TIK [19], kuesioner yang terdiri dari delapan bagian pun dibentuk. Pada makalah ini, hanya pertanyaan-pertanyaan yang digunakan yang dijelaskan, yaitu hanya tiga bagian.

Pada bagian pertama responden ditanyai tentang frekuensi perjalanan mingguan selama pandemi dan sebelum pandemi dalam enam jenis aktivitas di luar rumah, yaitu bekerja atau belajar, belanja bahan makanan, belanja elektronik/pakaian, makan di luar, bersantai, dan kegiatan sosial seperti mengunjungi kerabat atau keluarga. Selanjutnya, diberikan pertanyaan tentang kesehatan mental individu selama pandemi. Pertanyaan kesehatan mental terdiri dari delapan perasaan kognitif (frustrasi, bosan, kesal, lelah, khawatir, tertekan, tidak produktif, dan ketidaksabaran untuk mengakhirinya) dan satu evaluasi keseluruhan ("pengalaman terburuk dalam hidup saya"). Tanggapan tersebut ditangkap dalam bentuk skala Likert lima poin, mulai dari sangat tidak setuju (1) hingga sangat setuju (5). Kuesioner ditutup dengan karakteristik sosio-demografi dan spasial responden, seperti jenis kelamin, usia, pendapatan, pendidikan, pekerjaan, dan lokasi tempat tinggal. 
Data dikumpulkan saat pandemi COVID-19 terjadi di Indonesia. Sesuai dengan protocol untuk mengurangi resiko penularan melalui kontak fisik, pengumpulan data dilakukan secara online dengan menggunakan Google Form. Formulir kuesioner online diubah menjadi web-link dan didistribusikan melalui berbagai platform media sosial (Facebook, Instagram, Twitter, Line, dan WhatsApp). Rekrutmen responden menggunakan metode convenience sampling, dan dengan penyebaran secara online tersebut diatas pada relasi para peneliti dan dibantu dengan para mahasiswa dari universitas para peneliti. Convenience sampling digunakan karena keterbatasan survei secara fisik yang terjadi pada COVID-19, sehingga survei hanya dapat dilakukan secara online dengan bantuan jejaring sosial peneliti mahasiswa. Adapun untuk meningkatkan representasi data, perekrutan surveyor secara acak melalui media sosial juga dilakukan untuk melakukan penyebaran kuesioner secara online kepada kelompok sosial mereka. Survei dilakukan Mei hingga Juni 2020. Dari periode survei tersebut, 834 responden yang tinggal di beberapa provinsi di Indonesia dan menyelesaikan kuesioner

\subsection{Regresi Linear Berganda}

Dengan data pada variabel terikat yang merupakan data skala menerus, regresi linear berganda digunakan [20]. Regresi linear berganda merupakan metode statistika untuk memodelkan pengaruh variabel bebas dengan variabel terikat yang berbentuk skala menerus. Metode ini sudah sering digunakan dalam melakukan investigasi di berbagai subjek ilmu pengetahuan. Persamaan regresi linear dapat ditulis dengan [20].

dengan:

$$
Y=a+b_{1} X_{1}+b_{2} X_{2}+\cdots+b_{k} X_{k}+e
$$

$$
\begin{array}{ll}
\mathrm{Y} & =\text { variabel dependen } \\
\mathrm{a} & =\text { konstanta } \\
\mathrm{b} & =\text { koefisien regresi } \\
\mathrm{X} & =\text { variabel independen } \\
\mathrm{e} & =\text { error }
\end{array}
$$

Dikarenakan tujuan dari regresi linear ini adalah untuk menguji pengaruh antara variabel-variabel penelitian yang terdiri dari variabel dependen (terikat) dan independen (bebas), untuk makalah ini variabel terikat adalah perubahan aktivitas/perjalanan dan variabel bebas ini adalah perubahan kesehatan mental dan sosio demografi. Variabel sosio demografi dimasukan sebagai variabel bebas dikarenakan temuan pengaruhnya kepada perilaku perjalanan oleh berbagai studi [21]-[23]. Beberapa analisis dilakukan sebagai bagian dari pengujian kesesuaian model dengan data yaitu analisis variansi dan perhitungan koefisien determinasi $\left(\mathrm{R}^{2}\right)$.

\section{HASIL DAN PEMBAHASAN}

\subsection{Deskripsi Karakteristik Sosiodemografi}

Deskripsi karakteristik responden yang didapatkan dari survei ditujukkan pada Tabel 1. Berdasarkan total responden, sebagian besar merupakan masyarakat pada usia produktif bekerja, yaitu 26-60 tahun $(64,3 \%)$. Mayoritas jenis kelamin responden adalah laki-laki $(51,9 \%)$ dan memiliki pekerjaan sebagai karyawan swasta (38,4\%). Adapun dari sisi pendapatan, responden dengan pendapatan bulanan dalam kisaran Rp 2,5 hingga 5 juta/bulan dan Rp 5 hingga 10 juta/bulan mendominasi total responden, dengan $21,7 \%$ dan 23,7\% masing-masing. Adapun lokasi pemukiman responden sebagian besar tersebar di Bandung Raya, yaitu Kota Bandung dan sekitarnya sebesar 38,4\% dan Jabodetabek, yaitu Jakarta dan sekitarnya sebesar $31,1 \%$. 
Tabel 1. Karakteristik Demografi Responden $(\mathrm{N}=834)$

\begin{tabular}{|c|c|c|c|c|c|}
\hline \multicolumn{2}{|r|}{ Variabel } & $(\%)$ & \multirow{2}{*}{\multicolumn{2}{|c|}{ Sosio-demografi }} & $(\%)$ \\
\hline \multicolumn{3}{|c|}{ Sosio-demografi } & & & \\
\hline \multirow{5}{*}{ Usia } & $<18$ tahun & 2,0 & \multirow{7}{*}{ Pendapatan/uang saku } & $<1$ juta Rupiah & 19,1 \\
\hline & $18-25$ tahun & 31,4 & & $1-2,5$ juta Rupiah & 12,5 \\
\hline & $26-40$ tahun & 40,2 & & 2,6-5 juta Rupiah & 21,7 \\
\hline & $41-60$ tahun & 24,1 & & 5-10 juta Rupiah & 23,7 \\
\hline & $>55$ tahun & 2,3 & & 10-15 juta Rupiah & 10,6 \\
\hline \multirow{2}{*}{ Gender } & Pria & 51,9 & & $15-20$ juta Rupiah & 5,8 \\
\hline & wanita & 48,1 & & $>20$ juta Rupiah & 6,7 \\
\hline \multirow{9}{*}{ Pekerjaan } & Pelajar/mahasiswa & 27,9 & \multicolumn{2}{|c|}{ Karakteristik Tempat Tinggal } & \\
\hline & PNS/TNI/Polri & 7,1 & \multirow{5}{*}{ Lokasi Tempat Tinggal } & Bandung Raya & 38,4 \\
\hline & Pegawai Swasta & 38,4 & & Jabodetabek & 31,1 \\
\hline & Wiraswasta & 11,2 & & Surabaya, Semarang, dan Yogyakarta & 4,0 \\
\hline & Ibu Rumah Tangga & 6,0 & & Kota kecil lainnya di Jawa & 15,7 \\
\hline & Tidak Bekerja & 1,8 & & Diluar Jawa & 10,9 \\
\hline & Pensiunan & 1,3 & \multirow{3}{*}{ Status Tempat Tinggal } & Kepemilikan Sendiri & 79,3 \\
\hline & \multirow[t]{2}{*}{ Lainnya } & 6,4 & & Sewa & 12,5 \\
\hline & & & & Kost & 8,3 \\
\hline
\end{tabular}

\subsection{Deskripsi Kesehatan Mental Saat Pandemi COVID-19}

Selain itu, parameter kesehatan mental responden pada saat penerapan pembatasan sosial juga dijelaskan pada Tabel 2, yaitu perasaan negatif. Skala tanggapan yang menggunakan skala likert lima poin, mulai dari sangat tidak setuju sampai sangat setuju, hal ini menunjukkan bahwa sebagian besar rata-rata jumlah perasaan responden lebih tinggi dari nilai tengah 3 yang mewakili netral. Sebagian besar responden merasa bosan selama pandemi dan tidak sabar menunggu. Perasaan frustrasi dan depresi adalah kesejahteraan subjektif terendah yang dirasakan responden selama pandemi. Namun, evaluasi kesehatan mental secara keseluruhan dari pandemi, yang diindikasikan dengan 'pengalaman terburuk', menunjukkan nilai yang relatif netral $(3,06)$.

Tabel 2. Deskripsi Kesehatan Mental Saat Pandemi

\begin{tabular}{lrr}
\hline Saat pandemi ini saya merasa...* & Rata-rata & Standar Deviasi \\
\hline Frustrasi & 2.79 & 1.060 \\
Depresi & 2.64 & 1.026 \\
Khawatir & 3.81 & 0.915 \\
Bosan & 3.94 & 1.059 \\
Tidak produktif & 2.98 & 1.239 \\
Kesal & 3.23 & 1.081 \\
Lelah & 3.25 & 1.072 \\
Tidak sabar ini untuk berakhir & 4.19 & 0.966 \\
Pengalaman terburuk & 3.06 & 1.136 \\
\hline - sangat tidak setuju hingga 5 = sangat setuju
\end{tabular}

*skala Likert dengan 1 = sangat tidak setuju hingga 5 = sangat setuju

\subsection{Deskripsi Perubahan Aktivitas dan Perjalanan saat Pandemi COVID-19}

Hasil survei menunjukkan bahwa pandemi COVID-19 memang mengubah perilaku perjalanan masyarakat dan cara orang melakukan aktivitasnya. Ada penurunan tajam secara statistik dalam jumlah aktivitas di luar rumah dan peningkatan aktivitas online di rumah sebelum dan selama pandemi COVID19. Bagian atas Tabel 3 menunjukkan bahwa pandemi mengurangi frekuensi perjalanan mingguan orang untuk berbagai jenis tujuan, termasuk bekerja, sekolah, dll. Misalnya, frekuensi perjalanan rata-rata ke tempat kerja atau sekolah menurun dari awalnya pada 6,7 sebelum pandemi menjadi 2,77 selama pandemi. Dibandingkan dengan jenis perjalanan liburan/hiburan lainnya, perjalanan ke kantor atau sekolah mengalami penurunan paling tinggi sedangkan perjalanan belanja elektronik/ashion sedikit mengalami penurunan. Hal ini dikarenakan perjalanan ke kantor atau sekolah merupakan sesuatu yang 
wajib dilakukan setiap hari sedangkan perjalanan belanja barang elektronik/pakaian bukan merupakan kebutuhan sehari-hari dan biasanya dilakukan sesekali. Itu sebabnya frekuensi perjalanan ke kantor atau sekolah sensitif terhadap gangguan.

Penurunan frekuensi perjalanan kemungkinan besar disebabkan oleh ketakutan masyarakat akan penularan serta pembatasan yang diberlakukan oleh pemerintah yang biasanya disebut sebagai "lockdown" di banyak negara atau "circuit breaker" dalam kasus Singapura. Selama masa pembatasan, sebagian besar pusat kegiatan, kecuali yang vital, tidak boleh dibuka dan ini menjelaskan penurunan frekuensi perjalanan.

Tabel 3 juga menujukkan bahwa selama pandemi COVID-19, frekuensi mingguan dari berbagai jenis aktivitas online di rumah (termasuk bekerja dari rumah (WFH) atau sekolah dari rumah (SFH), aktivitas hiburan, dll.) meningkat dibandingkan periode sebelumnya. Frekuensi rata-rata WFH dan SFH meningkat dari 2,28 menjadi 5,49, sedangkan rata-rata frekuensi aktivitas hiburan online meningkat dari 4,51 menjadi 6,40. Sebab, meski ada pembatasan perjalanan, masyarakat tetap harus memenuhi kebutuhannya, sehingga mereka memilih untuk melakukan aktivitas tersebut secara online terutama untuk aktivitas WFH atau SFH dan hiburan. Kegiatan seperti belanja online atau pesan antar online makanan / minuman juga meningkat meskipun sedikit karena ini adalah kegiatan yang masih dapat dilakukan secara off-line tanpa harus bepergian jauh dari rumah. Selain itu, belanja elektronik/pakaian hanya meningkat sedikit karena aktivitas tersebut bukan kebutuhan sehari-hari dan seperti yang telah disebutkan sebelumnya, biasanya dilakukan sesekali.

Tabel 3. Karakteristik Frekuensi Perjalanan Sebelum dan Saat Pandemi Perminggu (kali/minggu)

\begin{tabular}{|c|c|c|c|c|c|c|c|}
\hline \multirow[t]{2}{*}{ Tipe Perjalanan } & \multicolumn{2}{|c|}{$\begin{array}{l}\text { Frekuensi Mingguan } \\
\text { Sebelum COVID-19 }\end{array}$} & \multicolumn{2}{|c|}{$\begin{array}{l}\text { Frekuensi Mingguan } \\
\text { Saat COVID-19 }\end{array}$} & \multicolumn{3}{|c|}{$\begin{array}{c}\text { Perubahan Frekuensi Mingguan Saat - } \\
\text { Sebelum COVID-19 }\end{array}$} \\
\hline & Mean & $S D$ & Mean & $S D$ & Mean & $S D$ & $t$-stat \\
\hline Pekerjaan/pedidikan & 6,70 & 3,309 & 2,77 & 2,84 & $-3,93$ & 3,688 & $-26,024 * *$ \\
\hline $\begin{array}{l}\text { Belanja kebutuhan } \\
\text { sehari-hari }\end{array}$ & 3,78 & 2,405 & 2,58 & 1,686 & $-1,20$ & 2,121 & $-11,791 * *$ \\
\hline $\begin{array}{l}\text { Belanja } \\
\text { elektronik/pakaian }\end{array}$ & 2,12 & 1,726 & 1,41 & 1,085 & $-0,71$ & 1,59 & $-10,074 * *$ \\
\hline Makan diluar rumah & 3,40 & 2,385 & 1,45 & 1,33 & $-1,95$ & 2,372 & $-20,631 * *$ \\
\hline Liburan/hiburan & 2,76 & 1,99 & 1,36 & 1,17 & $-1,40$ & 1,976 & $-17,462 * *$ \\
\hline Sosial & 3,59 & 2,458 & 1,89 & 1,63 & $-1,70$ & 2,245 & $-16,624 * *$ \\
\hline \multirow{2}{*}{$\begin{array}{l}\text { Type Aktivitas Daring } \\
\text { di Rumah }\end{array}$} & \multicolumn{2}{|c|}{$\begin{array}{l}\text { Frekuensi Mingguan } \\
\text { Sebelum COVID-19 }\end{array}$} & \multicolumn{2}{|c|}{$\begin{array}{l}\text { Frekuensi Mingguan } \\
\text { Saat COVID-19 }\end{array}$} & \multicolumn{3}{|c|}{$\begin{array}{l}\text { Perubahan Frekuensi Mingguan Saat - } \\
\text { Sebelum COVID-19 }\end{array}$} \\
\hline & Mean & $S D$ & Mean & $S D$ & Mean & $S D$ & $t$-stat \\
\hline E-meeting/e-learning & 2,28 & 2,351 & 5,49 & 3,782 & 3,21 & 3,743 & $20,786^{* *}$ \\
\hline $\begin{array}{l}\text { Belanja kebutuhan } \\
\text { sehari-hari online } \\
\text { Belanja }\end{array}$ & 2,16 & 1,729 & 2,89 & 2,166 & 0,73 & 1,842 & $7,583 * *$ \\
\hline $\begin{array}{l}\text { elektronik/pakaian } \\
\text { online }\end{array}$ & 1,80 & 1,433 & 2,07 & 1,769 & 0,27 & 1,418 & $3,377 * *$ \\
\hline $\begin{array}{l}\text { Belanja makanan } \\
\text { online }\end{array}$ & 3,67 & 2,577 & 3,80 & 2,80 & 0,13 & 2,652 & 1,019 \\
\hline Hiburan online & 4,51 & 3,554 & 6,40 & 3,597 & 1,89 & 2,931 & $10,799 * *$ \\
\hline
\end{tabular}

** signifikan pada 5\%

\subsection{Analisis Perubahan Aktivitas-Perjalanan dan Kesehatan Mental Saat Pandemi}

Dalam rangka melakukan analisis perubahan aktivitas-perjalanan dengan variabel bebas karakteristik kesehatan mental, dilakukan analisis faktor untuk melakukan optimalisasi variabel perubahan aktivitasperjalanan saat pandemi. Parameter kesesuaian pada analisis faktor disajikan pada tabel 4 . Hasil nilai reliabilitas variabel menujukkan angka Cronbach-alpha $>0,8$ pada variabel perjalanan dan 0,40 pada aktivitas online. Uji Kaiser-Mayer-Olkin (KMO) menunjukkan nilai lebih dari 0,6 menandakan faktor analisis sangat tepat dilakukan pada variabel pertanyaan yang ada serta uji Bartlett's test of sphericity 
menujukkan nilai signifikan $(<5 \%)$ [20]. Analisis faktor menghasilkan masing-masing satu faktor pada tipe perjalanan dan aktivitas online yang digunakan dalam analisis regresi linear pada analisis perubahan aktivitas perjalanan saat pandemi dan efek dari kesehatan mental pada perubahan tersebut.

Tabel 4. Analisis Faktor Perubahan Aktivitas - Perjalanan saat Pandemi

\begin{tabular}{|c|c|c|}
\hline Tipe Perjalanan & Component Factor Analysis & Cronbach alpha \\
\hline Pekerjaan/pedidikan & .663 & \multirow{6}{*}{0,818} \\
\hline Belanja kebutuhan sehari-hari & .648 & \\
\hline Belanja elektronik/pakaian & .742 & \\
\hline Makan diluar rumah & .819 & \\
\hline Liburan/hiburan & .866 & \\
\hline Sosial & .777 & \\
\hline 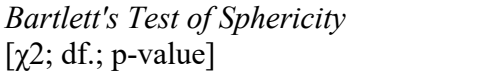 & \multicolumn{2}{|c|}{$[2009,393 ; 15 ; 0,000]$} \\
\hline KMO Measure of Sampling Adequacy & \multicolumn{2}{|l|}{0,853} \\
\hline Tipe Aktivitas Online di Rumah & Component Factor Analysis & Cronbach alpha \\
\hline E-meeting/e-learning & .528 & \multirow{5}{*}{0,450} \\
\hline Belanja kebutuhan sehari-hari online & .811 & \\
\hline Belanja elektronik/pakaian online & .724 & \\
\hline Belanja makanan online & 465 & \\
\hline Hiburan online & .392 & \\
\hline 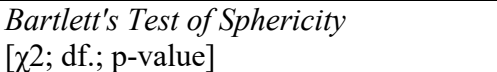 & \multicolumn{2}{|c|}{$[401,371 ; 10 ; 0,000]$} \\
\hline KMO Measure of Sampling Adequacy & 0,609 & \\
\hline
\end{tabular}

Analisis regresi linear berganda untuk investigasi perubahan aktivitas-perjalanan disajikan pada tabel 5 . Model regresi linear akan memahami hubungan antara kesehatan mental kepada perubahan aktivitasperjalanan. Selain itu variabel sosio demografi juga dimasukan menjadi variabel bebas. Data sosiodemografi yang dimasukan dalam bentuk dummy variable [20]. Sebelum melakukan intepretasi model, dilakukan evaluasi kelayakan model yang juga dideskripsikan pada tabel 4. Nilai uji ANOVA menujukkan nilai signifikansi sehingga model regresi dengan variabel bebas dapat digunakan untuk mengekplorasi variabel terikat. Nilai koefisien determinasi atau $\mathrm{R}^{2}$ menunjukkan cukup rendah pada kedua model. Beberapa penelitian menujukkan nilai $\mathrm{R}^{2}$ pada penelitian khususnya terkait dengan ekplorasi (explonatory research) variabel dapat rendah sehingga nilai $\mathrm{R}^{2}$ bukan suatu indikator utama model dapat diinterpretasikan atau tidak, namun menandakan dari effect size [24]. Namun dengan beberapa variabel signifikan yang berhubungan dengan variabel terikat, maka secara statistik model ini cukup baik untuk dilakukan intepretasi.

Tabel 5. Estimasi Model Perubahan Aktivitas-Perjalanan dan Kesehatan Mental Saat Pandemi

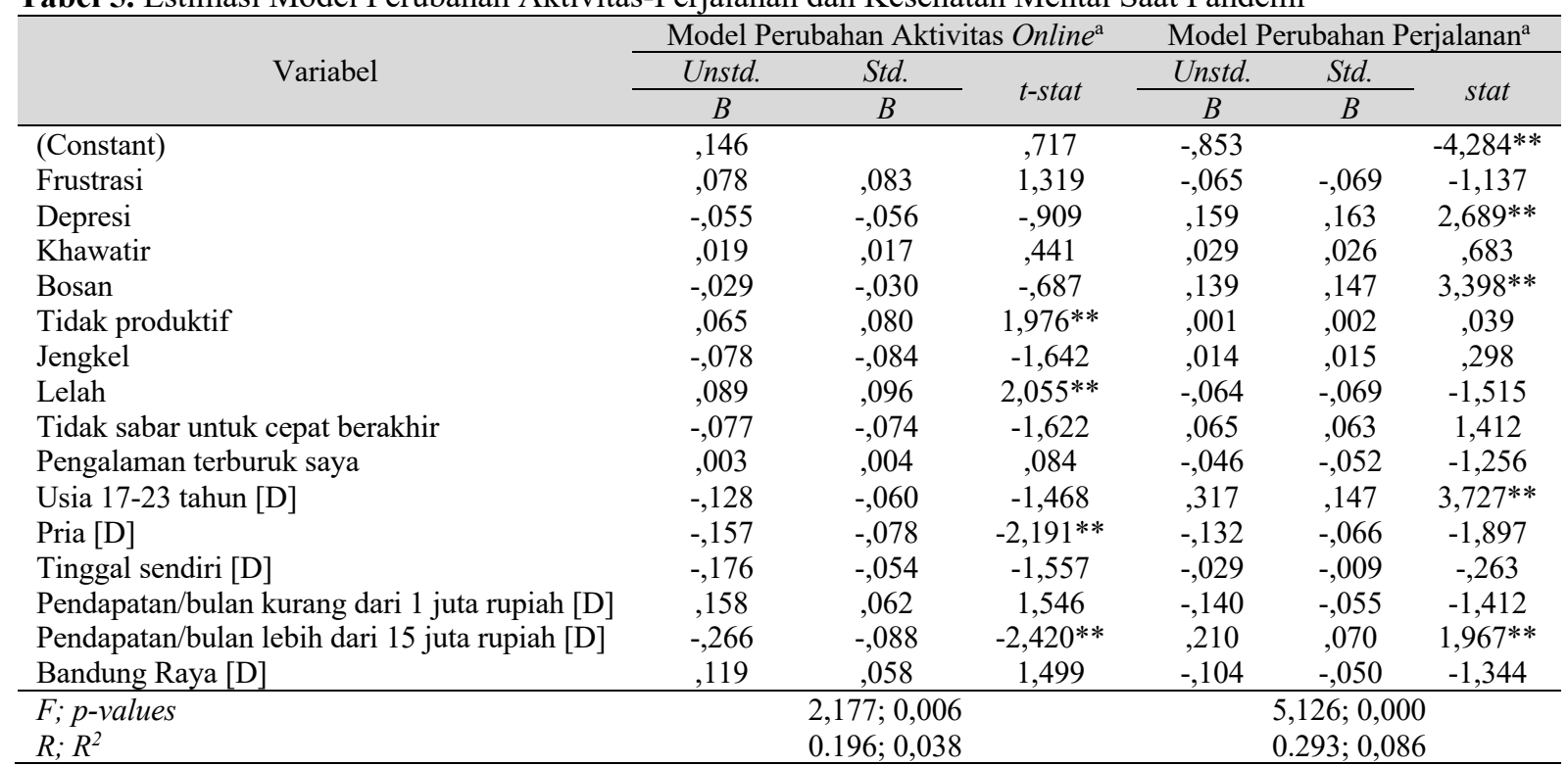

[D] dummy variable $=1$ jika ya, 0 lainnya; ** signifikan pada 5\%; ${ }^{a}$ perubahan frekuensi sebelum pandemi - saat pandemi 
Model perubahan aktivitas online menunjukkan pelaku perjalanan yang mengalami kelelahan saat pandemi cenderung berasosiasi dengan berkurangnya aktivitas online saat pandemi. Pelaku perjalanan yang merasa tidak produktif juga cenderung merupakan pelaku perjalanan yang mengurangi aktivitas online saat pandemi. Adapun pelaku perjalanan dengan pendapatan tinggi cenderung meningkatkan penggunaan TIK untuk aktivitas online saat pandemi. Pada model perubahan perjalanan saat pandemi, terdapat beberapa variabel yang signifikan mempengaruhi terjadinya perubahan perjalanan. Aspek kesehatan mental seperti depresi dan bosan cenderung berasosiasi pada pelaku perjalanan yang mengurangi frekuensi perjalanannya saat pandemi. Adapun usia pelajar dan mahasiswa cenderung tidak mengalami perubahan frekuensi perjalanan saat pandemi. Selain itu pelaku perjalanan dengan pendapatan tinggi cenderung mengurangi frekuensi perjalanannya saat pandemi.

\section{DISKUSI}

Pandemi COVID-19 telah secara signifikan mempengaruhi bagaimana kita menjalani kehidupan seharihari kita. Studi ini bertujuan untuk menginvestigasi perubahan aktivitas dan perjalanan saat pandemi di Indonesia. Dalam melakukan investigasi ini dilakukan integrasi dari pengaruh kesehatan mental saat pandemi dan aspek sosio demografi pelaku perjalanan.

Hasil analisis menujukkan bahwa telah terjadinya perubahan aktivitas dan perjalanan akibat dari pandemi COVID-19. Misalnya, frekuensi perjalanan rata-rata ke tempat kerja atau sekolah menurun sebesar 66\% selama pandemi. Dibandingkan dengan jenis perjalanan liburan/hiburan lainnya, perjalanan ke kantor atau sekolah mengalami penurunan paling tinggi sedangkan perjalanan belanja elektronik/ pakaian sedikit mengalami penurunan. Hal ini dikarenakan perjalanan ke kantor atau sekolah merupakan sesuatu yang wajib dilakukan setiap hari sedangkan perjalanan belanja barang elektronik / pakaian bukan merupakan kebutuhan sehari-hari dan biasanya dilakukan sesekali. Disisi lain aktivitas bekerja/belajar dari rumah meningkat hingga 3 kali lipat. Selain itu penggunaan aplikasi belanja online juga meningkat dengan pesat disebabkan masyarakat tetap harus memenuhi kebutuhannya, sehingga mereka memilih untuk melakukan aktivitas tersebut secara online terutama untuk aktivitas WFH atau SFH dan hiburan. Adapun penurunan kesehatan mental ditemukan berdasarkan hasil studi ini. Mayoritas pelaku perjalanan merasakan rasa bosan selama pandemi dan tidak sabar menunggu didorong dengan penerapan pembatasan sosial berskala besar. Perasaan frustrasi dan depresi adalah kesehatan mental yang sangat terdampak yang dirasakan pelaku perjalanan pada masa pandemi. Hal ini diduga berhubungan dengan berkurangnya kesempatan untuk pemenuhan kegiatan ekonomi maupun kegiatan hiburan dan sosial yang tidak dapat tergantikan oleh fasilitas TIK. Selain itu dengan menurunnya kinerja ekonomi yang berdampak kepada peningkatan penggangguran diduga berpengaruh kepada masyarakat khususnya yang sangat terdampak. Adapun evaluasi kesehatan mental secara keseluruhan menunjukkan nilai yang relatif netral.

Model perubahan perjalanan saat pandemi mengkonfirmasi dugaan bahwa perubahan kesehatan mental pada saat pandemi berkorelasi terhadap perubahan perilaku perjalanan dan aktivitas. Masyarakat yang memiliki penurunan kesehatan mental seperti depresi dan bosan sangat berkaitan dengan kurangnya aktivitas diluar rumah saat pandemi. Hal ini berkaitan dengan aktivitas dirumah yang berhubungan dengan pemenuhan kesehatan mental [18], sehingga dengan terbatasnya kegiatan diluar rumah, pelaku perjalanan merasakan kekurangan dan keterbatasan dari kebutuhannya. Pelaku perjalanan yang mengalami kelelahan saat pandemi cenderung berasosiasi dengan berkurangnya aktivitas online saat pandemi. Hal ini diduga terjadi karena akses kepada kegiatan online masih terbatas dibeberapa lokasi di Indonesia sehingga belum meratanya penggunaan hal tersebut. Seragam dengan hal tersebut, studi Mokhtarian [19] menggarisbawahi bahwa adaptasi TIK untuk mengganti kebutuhan perjalanan sangat berkaitan dengan tersedianya infrastruktur, teknologi, serta kapasitas pengguna. Disisi lain aksesibilitas dalam hal kapasitas finansial sangat berkaitan dengan adaptasi TIK yang lebih tinggi. Hal ini sangat 
berkaitan dengan mudahnya masyarakat berpedapatan tinggi untuk mendapatkan/membeli teknologi TIK terkini untuk melakukan kegiatan online daripada masyarakat berpendapatan rendah. Menariknya, masyarakat berpendapatan tinggi juga cenderung lebih mengurangi perjalanannya saat pandemi.

\section{KESIMPULAN}

Studi ini mengkonfirmasi bahwa terdapat perubahan aktivitas dan perjalanan saat pandemi COVID-19 dan perubahan ini berhubungan dengan penurunan kesehatan mental. Hasil analisis menunjukkan bahwa beberapa tipe kesehatan mental seperti depresi dan bosan sangat berkaitan dengan penurunan pola perjalanan, sedangkan kelelahan berkaitan dengan kurangnya aksesiblitas kepada kegiatan TIK. Studi ini juga menemukan bahwa masyarakat berpendapatan tinggi, memiliki kesempatan aksesbilitas kepada TIK yang tinggi, cenderung melakukan kegiatan online lebih banyak dan juga mengurangi perjalanan mereka keluar tempat tinggal.

Berdasarkan temuan tersebut beberapa rekomendasi dapat disampaikan. Pertama peningkatan kualitas infrastrutkur TIK ditemukan berkorelasi terhadap pemenuhan kebutuhan mental, sehingga pembenahan kualitas internet atau subsidi internet direkomendasikan untuk menjadi agenda prioritas pemerintah maupun swasta. Peningkatan ini dapat juga membantu usaha masyarakat sehingga perekonomian masyarakat dapat terbantu. Kedua, pemerintah perlu melakukan antisipasi penurunan kesehatan mental seperti bosan atau depresi dikarenakan karantina dengan pembangunan fasilitas aktif diluar rumah seperti taman disekitar perumahan untuk mencegah kebosanan atau depresi. Menyeimbangkan kegiatan dirumah dan kegiatan aktif tersebut dapat mengurangi tingkat kebosanan atau depresi saat pandemi namun tetap sesuai dengan protokol kesehatan. Diharapkan dengan pembenahan ini tidak hanya dapat dilakukan manajemen pergerakan pada pandemi, namun juga tetap menjaga kesehatan mental masyarakat.

\section{UCAPAN TERIMA KASIH}

Penelitian ini dibiayai oleh hibah dosen muda Institut Teknologi Nasional Bandung. Para penulis berterimakasih pada pihak-pihak yang membantu pengumpulan data.

\section{DAFTAR PUSTAKA}

[1] S. Null and H. Smith, "COVID-19 Could Affect Cities for Years. Here Are 4 Ways They're Coping Now," Mar. 26, 2020. https://wri-indonesia.org/en/blog/how-cities-coping-with-covid-19 (accessed Jun. 06, 2020).

[2] C. Musselwhite, E. Avineri, and Y. Susilo, "Editorial JTH 16 -The Coronavirus Disease COVID-19 and implications for transport and health," J. Transp. Health, vol. 16, p. 100853, Mar. 2020, doi: 10.1016/j.jth.2020.100853.

[3] Moovit, "Moovit Public Transit Index," May 2020. https://moovitapp.com/insights/en/Moovit_Insights_Public_Transit_Index-countries (accessed Jun. 10, 2020).

[4] UITP, "Bus operations in India: what has been the impact of COVID-19?," UITP, May 27, 2020. https://www.uitp.org/news/bus-operations-india-what-has-been-impact-covid-19 (accessed Jun. $10,2020)$.

[5] CNN Indonesia, "Corona Bikin Transjakarta, KRL, MRT, dan LRT Sepi Penumpang," ekonomi, Apr. 20, 2020. https://www.cnnindonesia.com/ekonomi/20200420111334-92-495176/coronabikin-transjakarta-krl-mrt-dan-lrt-sepi-penumpang (accessed Jun. 10, 2020).

[6] J. Clement, "COVID-19 impact retail e-commerce site traffic 2020," Statista, Jun. 03, 2020. https://www.statista.com/statistics/1112595/covid-19-impact-retail-e-commerce-site-trafficglobal/ (accessed Jun. 10, 2020). 
[7] A. Kunst, "Online shopping due to the COVID-19 pandemic 2020," Statista, Jun. 02, 2020. https://www.statista.com/statistics/1107859/shifting-to-online-purchases-because-of-the-covid19-pandemic-by-category/ (accessed Jun. 10, 2020).

[8] Y. Pusparisa, "E-Commerce Tumbuh di Tengah Pandemi Covid-19," May 20, 2020. https://katadata.co.id/infografik/2020/05/20/e-commerce-tumbuh-di-tengah-pandemi-covid-19 (accessed Jun. 10, 2020).

[9] J. De Vos, "The effect of COVID-19 and subsequent social distancing on travel behavior," Transp. Res. Interdiscip. Perspect., vol. 5, p. 100121, May 2020, doi: 10.1016/j.trip.2020.100121.

[10] S. K. Brooks et al., "The psychological impact of quarantine and how to reduce it: rapid review of the evidence," The Lancet, vol. 395, no. 10227, pp. 912-920, Mar. 2020, doi: 10.1016/S01406736(20)30460-8.

[11] J. McKimm, "Life in lockdown: how the COVID-19 pandemic complicates existing mental health conditions," May 08, 2020. https://rcni.com/nursing-standard/features/life-lockdown-howcovid-19-pandemic-complicates-existing-mental-health-conditions-160426 (accessed Jun. 07, 2020).

[12] D. Campbell, "UK lockdown causing "serious mental illness in first-time patients," the Guardian, May 15, 2020. http://www.theguardian.com/society/2020/may/16/uk-lockdowncausing-serious-mental-illness-in-first-time-patients (accessed Jun. 07, 2020).

[13] S. M. Kissler, C. Tedijanto, E. Goldstein, Y. H. Grad, and M. Lipsitch, "Projecting the transmission dynamics of SARS-CoV-2 through the postpandemic period," Science, vol. 368, no. 6493, pp. 860-868, May 2020, doi: 10.1126/science.abb5793.

[14] M. Roberts, F. Gil Sander, and S. Tiwari, “Augment, Connect, Target: Realizing Indonesia's Urban Potential," World Bank, Text/HTML, 2019. Accessed: Mar. 31, 2020. [Online]. Available: https://www.worldbank.org/en/country/indonesia/publication/augment-connecttarget-realizing-indonesias-urban-potential.

[15] R. Djalante et al., "Review and analysis of current responses to COVID-19 in Indonesia: Period of January to March 2020," Prog. Disaster Sci., vol. 6, p. 100091, Apr. 2020, doi: 10.1016/j.pdisas.2020.100091.

[16] K. W. Axhausen, "Activity Spaces, Biographies, Social Networks and their Welfare Gains and Externalities: Some Hypotheses and Empirical Results," Mobilities, vol. 2, no. 1, pp. 15-36, Mar. 2007, doi: 10.1080/17450100601106203.

[17] M. Kroesen, S. Handy, and C. Chorus, "Do attitudes cause behavior or vice versa? An alternative conceptualization of the attitude-behavior relationship in travel behavior modeling," Transp. Res. Part Policy Pract., vol. 101, pp. 190-202, Jul. 2017, doi: 10.1016/j.tra.2017.05.013.

[18] D. Ettema, T. Gärling, L. E. Olsson, and M. Friman, "Out-of-home activities, daily travel, and subjective well-being,” Transp. Res. Part Policy Pract., vol. 44, no. 9, pp. 723-732, Nov. 2010, doi: 10.1016/j.tra.2010.07.005.

[19] P. L. Mokhtarian, "If telecommunication is such a good substitute for travel, why does congestion continue to get worse?:," Transp. Lett., vol. Vol 1, no. No 1, pp. 1-17, 2009.

[20] J. F. Hair, W. C. Black, B. J. Babin, and R. E. Anderson, Multivariate Data Analysis. Harlow, Essex: Pearson, 2010.

[21] M. Z. Irawan, M. Rizki, T. B. Joewono, and P. F. Belgiawan, "Exploring the intention of out-ofhome activities participation during new normal conditions in Indonesian cities," Transp. Res. Interdiscip. Perspect., vol. 8, p. 100237, Nov. 2020, doi: 10.1016/j.trip.2020.100237.

[22] M. Rizki, T. B. Joewono, P. F. Belgiawan, and M. Z. Irawan, "The travel behaviour of ridesourcing users, and their perception of the usefulness of ride-sourcing based on the users' previous modes of transport: A case study in Bandung City, Indonesia," IATSS Res., Dec. 2020, doi: 10.1016/j.iatssr.2020.11.005. 
[23] M. Rizki, T. B. Joewono, and P. F. Belgiawan, "Travel Experience and Multitasking of Toll Road Users in Jakarta Metropolitan Area, Indonesia: An Investigation for Passenger of Private Car, Taxi, and Ride-sourcing," J. East. Asia Soc. Transp. Stud., vol. 13, pp. 523-541, 2019, doi: 10.11175/easts.13.523.

[24] M. H. Kutner, Applied Linear Statistical Models. McGraw-Hill Irwin, 2005. 